\title{
Probiotic preparation reduces faecal water genotoxicity and cytotoxicity in chickens fed ochratoxin A contaminated feed (in vivo study)*
}

\author{
Katarzyna Śliżewska ${ }^{1 凶}$, Adriana Nowak and Stefania Smulikowska² \\ IInstitute of Fermentation Technology and Microbiology, Lodz University of Technology, Łódź, Poland; 2Polish Academy of Sciences, \\ The Kielanowski Institute of Animal Psysiology and Nutrition, Jabłonna, Poland
}

The aim of the present study was to assess the genotoxicity and cytotoxicity of the faecal water of chickens fed ochratoxin A (OTA) contaminated feed with and without probiotic preparation. The study was performed on 20 healthy female Ross broiler chickens divided into 4 groups: control chickens - fed with non-supplemented feed; PP chickens - fed feed supplemented with the probiotic preparation; OTA chickens - fed feed contaminated with $1 \mathrm{mg}$ per $\mathrm{kg}$ of OTA; OTA + PP chickens - fed feed contaminated with $1 \mathrm{mg}$ per $\mathrm{kg}$ of OTA and supplemented with the probiotic preparation. Faecal water samples were collected on the $35^{\text {th }}$ day of life of chickens from each group. Genotoxicity was measured using the comet assay, and cytotoxicity by means of MTT tests. Mean DNA damage, measured as the percentage of DNA in the tails of the comets, was $8.50 \pm 1.10$ for chickens fed OTA at $1 \mathrm{mg} / \mathrm{kg}$ and $6.41 \pm 0.67$ in the controls. The supplementation of feed with the probiotic preparation decreased the extent of DNA damage to $4.74 \pm 0.78$. In the control group of chickens the average cytotoxicity was $38.5 \pm 0.5$ (in MTT), while in the probiotic preparation group (PP group) it was $31.8 \pm 0.7$ (in MTT). After supplementation of the feed with the probiotic preparation, the genotoxicity and cytotoxicity were decreased in a statistically significant manner.

Key words: ochratoxin A, probiotics, chicken, genotoxicity, cytotoxicity

Received: 15 July, 2015; revised: 08 September, 2015; accepted: 09 October, 2015; available on-line: 07 January, 2016

\section{INTRODUCTION}

Mycotoxins are secondary fungal metabolites and remain the subject of major concern throughout the world. Where present, they usually occur as trace contaminants in agricultural products, in concentrations ranging from nanogram to microgram quantities per gram of material. Intensive research on mycotoxins has been conducted for the past 35 years. The first group of mycotoxins which was isolated and described in 1961, in the wake of several acute animal disease outbreaks in 1960, consisted of aflatoxins (Goldblatt, 1969). After the discovery of aflatoxins, ochratoxins were the next major group of mycotoxins identified (van der Merwe et al., 1965). It was typical for mycotoxicoses in general that a seasonal peak in the occurrence of a toxin drew attention to the agents which triggered acute clinical diseases. Such acute intoxications can be dramatic and economically devastating, but they constitute only a small fraction of the biological and economic consequences of the more usual chronic intoxications caused by lower levels of toxin (Rocha et al., 2014).

Data published by FAO in 2001 show that $25 \%$ of agricultural products are contaminated with mycotoxins, with their type and concentration largely dependent on the climatic zone. In spite of the fact that in Europe we can observe less favorable conditions for the synthesis of mycotoxins than e.g. in North America or Asia, the problem of mycotoxins in grains is a very important issue also for many European countries (primarily the Scandinavian countries, the southern parts of Germany as well as Austria and Italy) (FAO/WHO, 2001). Therefore, the contamination of animal feeds with mycotoxins is considered to be a world-wide problem (Siegel and Babusco, 2011).

Ochratoxin A (OTA), a secondary metabolite with teratogenic, hepatotoxic, carcinogenic and nephrotoxic activity in many animal species, including human beings (Höhler, 1998), is mainly produced by Aspergillus ochraceus and Penicillium viridicatum. Being ubiquitous, these moulds can easily contaminate foodstuffs. OTA is predominantly found in cereal grains, cereal products, legumes, oilseed, coffee beans and animal feed. Moreover, OTA has been identified in the tissue and organs of animals (pigs, chicken) fed contaminated feed. The presence of OTA has also been reported in human milk. The IARC (International Agency for Research in Cancer) has classified OTA as Group 2B, a possible human carcinogen (IARC, 1993). In several areas of Eastern Europe, where chronic exposure to OTA occurs, involvement of this mycotoxin in the aetiology of cancer of the urinary system and in kidney pathologies typical of Balkan Endemic Nephropathy (BEN) has been suspected. Studies on the correlation between OTA and BEN (Puntaric et al., 2001) have shown higher OTA contamination levels in cereals from endemic areas with respect to cereals from non-endemic areas (Muscarella et al., 2004).

Protection against mycotoxin contamination of raw plant material which is to be biotechnologically processed and used as animal feed focuses on its growth requirements, harvest and storage (Fraga et al., 2007).

e-mail: katarzyna.slizewska@p.lodz.p

*The results were presented at the 6th International Weigl Conference on Microbiology, Gdańsk, Poland (8-10 July, 2015).

Abbreviations: DAPI, 4'6-diamidino-2-phenylindole; DMEM, Dulbecco's Modified Eagle's Minimal Essential Medium; EDTA, ethylenediaminetetraacetic acid; FAO, Food and Agriculture Organization of the United Nations; MTT test, reduction assay the tetrazolium 3-(4,5-dimethylthiazol-2-yl)-2,5-diphenyltetrazolium bromide; OTA, ochratoxin A; PP, probiotic preparation 
However, sometimes it is very difficult to minimise the production of toxins by moulds, especially if a crop is exposed to changeable weather conditions favourable to contamination of cereals with moulds and their toxic products. If plant material is contaminated with mycotoxins, it should be subject to detoxification (Akande et al., 2006). In the case of feed, FAO accepts the methods of eliminating toxins by means of chemical compounds and physical processes which fulfil several requirements, concerning e.g. the preservation of the nutritive and sensory value and physical properties of products, as well as the economic justification for the decontamination process (Allameh et al., 2005).

Biological detoxication of mycotoxins in food, raw material and concentrated feed as well as in human and animal organisms is a new and very promising method. Microorganisms used for the elimination of mycotoxins include lactic acid bacteria Lactobacillus sp. and yeast Saccharomyces sp. (El-Nezami et al., 2000; Shetty \& Jespersen, 2006). Particular attention is paid to lactic acid bacteria (LAB), because they can contribute to the inhibition of mould development and production of mycotoxins (Haskard et al., 2001; Slizewska et al., 2010).

The aim of the present study was to assess the influence of the probiotic preparation on the genotoxicity and cytotoxicity of the faecal water of chickens fed OTA contaminated feed with and without probiotic preparation.

\section{MATERIALS AND METHODS}

Probiotic preparation. The probiotic preparation consisted of (per $1 \mathrm{~kg}$ ): $10^{10}$ Lactobacillus cells (Lb. paracasei LOCK 0920, Lb. brevis LOCK 0944 and Lb. brevis LOCK 0945), $10^{6}$ yeast Saccharomyces cerevisiae LOCK 0140 and $50 \mathrm{~g}$ of Yucca Schidigera extract. The strains were from the Collection of Industrial Microorganisms (LOCK), Institute of Fermentation Technology and Microbiology, Technical University of Lodz, Poland. The strains used in the study for the preparation possess full probiotic documentation (Śliżewska et al., 2012) and are licensed (Michalowski et al., 2012).

Treatment of animals. The study was performed on 20 healthy female Ross broiler chickens divided into 4 groups, 5 animals each, kept separately at the Institute of Animal Physiology and Nutrition, Polish Academy of Sciences, Jabłonna, Poland. The groups were: control chickens - fed non-supplemented feed; PP chickens fed feed supplemented with the probiotic preparation $(2$ $\mathrm{g} / \mathrm{kg}$ of feed between $1^{\text {st }}$ and $14^{\text {th }}$ day of life and $1 \mathrm{~g} / \mathrm{kg}$ until the end of the experiment); OTA chickens - fed feed contaminated with $1 \mathrm{mg}$ per $\mathrm{kg}$ of OTA; OTA + $\mathrm{PP}$ chickens - fed feed contaminated with $1 \mathrm{mg}$ per $\mathrm{kg}$ of OTA and supplemented with the probiotic preparation. All experimental procedures involving animals were conducted according to the Polish legal regulations concerning experiments on animals (following a decision issued by the Local Ethical Committee for Experiments on Animals at the University of Life Sciences in Warsaw).

Faecal water preparation. Faecal water samples were collected on the $35^{\text {th }}$ day of life, for each diet, in plastic bags, sealed and stored at $-20^{\circ} \mathrm{C}$ until analysis. Faecal water samples were extracted from faeces by homogenising the faeces with sterile water $(1: 5, \mathrm{v} / \mathrm{v})$ for $2 \mathrm{~min}$ followed by centrifugation $\left(10700 \times g, 40 \mathrm{~min}, 4^{\circ} \mathrm{C}\right)$. The supernatant fractions were distributed to $1.5 \mathrm{ml}$ Eppendorf tubes and stored at $-20^{\circ} \mathrm{C}$ prior to analysis.
Lymphocyte isolation and cell treatment. Blood was obtained from young, healthy, non-smoking donors. Peripheral blood lymphocytes were isolated by centrifugation at a density gradient of Histopaque-1077 (15 min, $182 \times g)$ (Sigma). The pellet containing peripheral blood lymphocytes was suspended in RPMI 1640 medium (Sigma). The final concentration of the lymphocytes in each sample was adjusted to $1 \times 10^{5}$ cells $/ \mathrm{ml}$. Lymphocytes were incubated with $10 \%$ faecal water for $1 \mathrm{~h}$ at $37^{\circ} \mathrm{C}$. In addition to the dietary treatments, two additional treatments were included in order to validate the assay. These treatments included control cells that only received the RPMI 1640 medium and a treatment in which cells were treated with hydrogen peroxide at $20 \mu \mathrm{M}$ applied for $10 \mathrm{~min}$ at $4^{\circ} \mathrm{C}$.

Caco-2 cell culture and treatment. The cells were cultured in Roux flasks as monolayer in Dulbecco's Modified Eagle's Minimal Essential Medium (DMEM, Sigma) with the addition of 10\% FBS (Gibco), $200 \mathrm{mM}$ L-glutamine (Sigma), 25 mM HEPES (Sigma), 100 IU/ $\mathrm{ml}$ penicillin (Sigma) and $100 \mu \mathrm{g} / \mathrm{ml}$ streptomycin (Sig$\mathrm{ma}$ ). The cells were incubated in a $\mathrm{CO}_{2}$ incubator at $37^{\circ} \mathrm{C}$ in $5 \% \mathrm{CO}_{2}$ for $7-10$ days to become fully differentiated. After reaching confluence, the cells were subcultivated every week. The medium was changed every 2-3 days. Caco-2 cells were tripsinised with 1\% trypsinEDTA (Sigma) for $2 \mathrm{~min}$ and gently shaken off the plastic flask. The reaction was terminated by addition of $10 \mathrm{ml}$ of DMEM with 10\% FBS. For the removal of trypsin, the cell suspension was transferred to a $15 \mathrm{ml}$ Falcon tube, centrifuged $(182 \times g, 5 \mathrm{~min})$, decanted and resuspended in DMEM. After the determination of cell count and viability by trypan blue, the cells were ready to use.

Comet assay. After incubation, the cells were centrifuged $\left(182 \times g, 15 \mathrm{~min}, 4^{\circ} \mathrm{C}\right)$ and the comet assay was performed in alkaline conditions according to the procedure of Singh et al. (1988) with some modifications (Blasiak and Kowalik, 2000). The cells were suspended in $0.75 \%$ LMP agarose and layered onto slides precoated with $0.5 \%$ agarose and lysed for $1 \mathrm{~h}$ at $4^{\circ} \mathrm{C}$ in a buffer consisting of $2.5 \mathrm{M} \mathrm{NaCl}, 1 \%$ Triton X-100, $100 \mathrm{mM}$ EDTA and $10 \mathrm{mM}$ Tris. After lysis, the slides were placed in an electrophoresis unit and DNA was allowed to unwind for 20 minutes in an electrophoretic solution containing $300 \mathrm{mM} \mathrm{NaOH}$ and $1 \mathrm{mM}$ EDTA. Electrophoresis was conducted at $4^{\circ} \mathrm{C}$ for 20 minutes at an electric field strength of $0.73 \mathrm{~V} / \mathrm{cm}(30 \mathrm{~mA})$. Then, the slides were neutralized with $0.4 \mathrm{~mol} / 1$ Tris and stained with $1 \mu \mathrm{g} / \mathrm{ml}$ DAPI (4',6-diamidino-2-phenylindole) and covered with cover slips. Comets were observed at $200 \times$ magnification with a fluorescence microscope (Nikon, Japan) attached to a video camera and connected to a personal computer-based image analysis system LuciaComet v. 4.51 (Laboratory Imaging, Prague, The Czech Republic). Fifty images were selected from each sample, and DNA damage was measured as the percentage of DNA in the tail of the comets. Two parallel tests with aliquots of the same sample were performed for a total of 100 cells and mean DNA damage was calculated. Each experiment was repeated three times. Comet results were analysed using two-way analysis of variance (ANOVA) while a particular mode of interaction $\times$ time was used to compare effects evoked by chemicals at this mode of interaction and suitable control. As no statistically significant interaction was found, one-way analysis of variance was applied. Differences between the means were compared using Scheffe's multiple comparison test. Results were presented as mean \pm S.E.M. 
Table 1. DNA damage measured as a percentage of DNA in the comet tail in an alkaline comet assay in human peripheral blood lymphocytes induced by faecal water of broiler chickens.

\begin{tabular}{lllll}
\hline \multirow{2}{*}{$\begin{array}{l}\text { Chicken num- } \\
\text { ber }\end{array}$} & \multicolumn{1}{l}{ Control } & PP & OTA & OTA + PP \\
\cline { 2 - 5 } & DNA [\%] in comet tail \pm S.E.M. & \\
\hline 1 & $8.19 \pm 1.48$ & $6.17 \pm 0.01$ & $10.43 \pm 0.64$ & $6.79 \pm 0.46$ \\
\hline 2 & $5.90 \pm 1.24$ & $4.93 \pm 1.40$ & $9.28 \pm 0.86$ & $6.27 \pm 0.70$ \\
\hline 3 & $6.90 \pm 1.07$ & $6.82 \pm 1.62$ & $8.13 \pm 3.96$ & $3.94 \pm 0.46$ \\
\hline 4 & $7.49 \pm 2.27$ & $4.14 \pm 0.51$ & $3.70 \pm 0.52$ & $2.60 \pm 0.48$ \\
\hdashline 5 & $4.15 \pm 0.81$ & $4.99 \pm 1.46$ & $7.78 \pm 2.35$ & $4.09 \pm 0.42$ \\
\hline Mean ${ }^{a} \pm$ S.E.M. & $6.41 \pm 0.67$ & $5.30^{*} \pm 0.59$ & $8.50 \pm 1.10$ & $4.74 * * 0.78$ \\
\hline
\end{tabular}

The number of cells analysed in each treatment was 100. Data are mean values $\left( \pm\right.$ S.E.M.) from all chickens in each group for which faecal samples were available. ${ }^{a}$ the results displayed are the mean of three independent experiments; ${ }^{*},{ }^{* *}$ statistically different from: *control, ${ }^{* *}$ OTA $(1 \mathrm{mg} / \mathrm{kg})$, ANOVA $(P<0.05)$.

Cytotoxicity testing. Caco-2 cells were added at $5 \times 10^{3}$ cells/well in 96 well plates and $80 \mu \mathrm{l}$ of culture medium was added into each well. The cells were then incubated at $37^{\circ} \mathrm{C}$ overnight in $5 \% \mathrm{CO}_{2}$ to allow them to attach to the plates. Next, a $20 \mu \mathrm{l}$ aliquot of the appropriate sample of chicken faecal water was added to each well. The cells were incubated in a $\mathrm{CO}_{2}$ incubator at $37^{\circ} \mathrm{C}$ in $5 \% \mathrm{CO}_{2}$ for $72 \mathrm{~h}$. After incubation, the cells were washed twice with PBS/EDTA, and $100 \mu \mathrm{l}$ of MTT $(0.5 \mathrm{mg} / \mathrm{ml}$ in PBS) was added into each well. The cells were further incubated at $37^{\circ} \mathrm{C}$ in $5 \% \mathrm{CO}_{2}$ for $3 \mathrm{~h}$. After incubation, the neutral red was carefully taken off and $50 \mu \mathrm{l}$ of desorbing solution (1\% acetic acid, $50 \%$ ethanol and $49 \%$ distilled water) was added to each well. In the MT'T test, the formazan precipitates were solubilized by the addition $50 \mu \mathrm{l}$ of DMSO (Sigma). The absorbance was measured at $550 \mathrm{~nm}$ using a microplate reader (ASYS, Biogenet). The absorbance of the control sample (Caco-2 cells in DMEM) was set at as $100 \%$ cell viability.
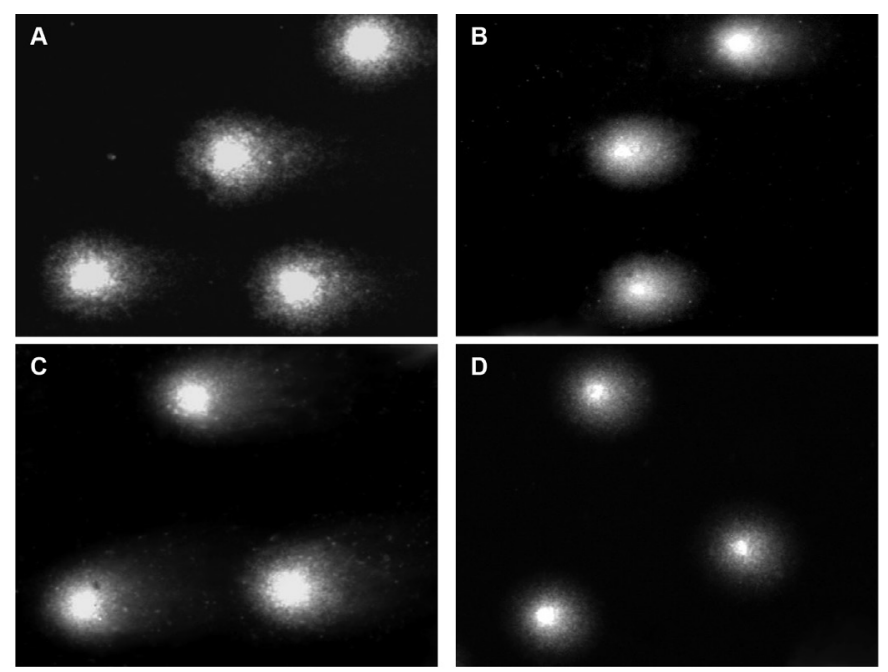

Figure 1. Representative comets of DAPI stained human blood lymphocytes incubated for $1 \mathrm{~h}$ at $37^{\circ} \mathrm{C}$ with faecal water of broiler chickens: (A) control groups of chickens; (B) chickens fed with fodder supplemented with probiotic preparation; (C) chickens fed with fodder contaminated with $1 \mathrm{mg} / \mathrm{kg}$ of OTA; (D) chickens fed with fodder contaminated with 1 $\mathrm{mg} / \mathrm{kg}$ of OTA and supplemented with probiotic preparation.
Analysis was performed in three independent experiments, each conducted in triplicate.

$\%$ cell viability $=($ sample O.D. $/$ control O.D. $)$

$\times 100 \%$

$\%$ cytotoxicity $=100-\%$ cell viability

Indicate main effect and interactive terms for the two-way ANOVA.

Results were presented as mean \pm S.D.

\section{RESULTS}

\section{Genotoxicity}

Non-exposed samples (cells in RPMI 1640, the negative control) displayed DNA damage levels of $1.45 \pm 0.84$. Treatment of the cells with $20 \mu \mathrm{M}$ hydrogen peroxide (positive control samples) resulted in damage levels of $26.36 \pm 1.62$ (results from three independent experiments).

Supplementation of the feed with the probiotic preparation only $(\mathrm{PP}$ - probiotic group of chickens) decreased the genotoxicity of faecal water compared to the control group of chickens (with no supplementation) (Table 1). In the control group, DNA damage was in the range from $4.15 \pm 0.81$ to $8.19 \pm 1.48$ (with the mean value of $6.41 \pm 0.67$ ), while in the probiotic preparation group of chickens (PP group) it was from $4.14 \pm 0.51$ to $6.82 \pm 1.62$ (with the mean value of $5.30 \pm 0.59)$ (Table 1, Fig. 1A and B). The results were statistically significant as marked in the Table 1.

Incubation of human lymphocytes with the faecal water of the chickens induced considerable DNA damage, yielding comet tails ranging from $3.70 \pm 0.52$ to $10.43 \pm 0.64$ (with the mean value of $8.50 \pm 1.10$ ) for chickens fed feed contaminated with $1 \mathrm{mg} / \mathrm{kg}$ of OTA (OTA group) (Table 1 and Fig. 1C).

After supplementation of the feed with the probiotic preparation, we observed a statistically significant decrease in the level of DNA damage, which was in the range from $2.60 \pm 0.48$ to $6.79 \pm 0.67$ (with the mean value of $4.74 \pm 0.78$ ) for chickens fed with feed contaminated with $1 \mathrm{mg} / \mathrm{kg}$ of OTA (OTA + PP group). Supplementation with the probiotic preparation reduced the genotoxicity of faecal water in chickens fed feed contaminated with 1 $\mathrm{mg} / \mathrm{kg}$ of OTA (Table 1 and Fig. 1D).

\section{Cytotoxicity}

Supplementation of the feed with the probiotic preparation only ( $\mathrm{PP}$ - probiotic group of chickens) statistically decreased the cytotoxicity of faecal water compared to the control group of chickens (with no supplementation) (Fig. 2). In the control group of chickens, the average cytotoxicity was $38.5 \pm 0.5$, while in the probiotic preparation group (PP group) it was $31.8 \pm 0.7$ (Fig. 2).

Incubation of Caco- 2 cells with the faecal water of chickens fed feed contaminated with 1 $\mathrm{mg} / \mathrm{kg}$ OTA (OTA group) induced considerable cytotoxicity with a mean value of $53.9 \pm 0.4$ for chickens fed with feed contaminated with $1 \mathrm{mg} /$ $\mathrm{kg}$ of OTA (OTA group) (Fig. 2). 


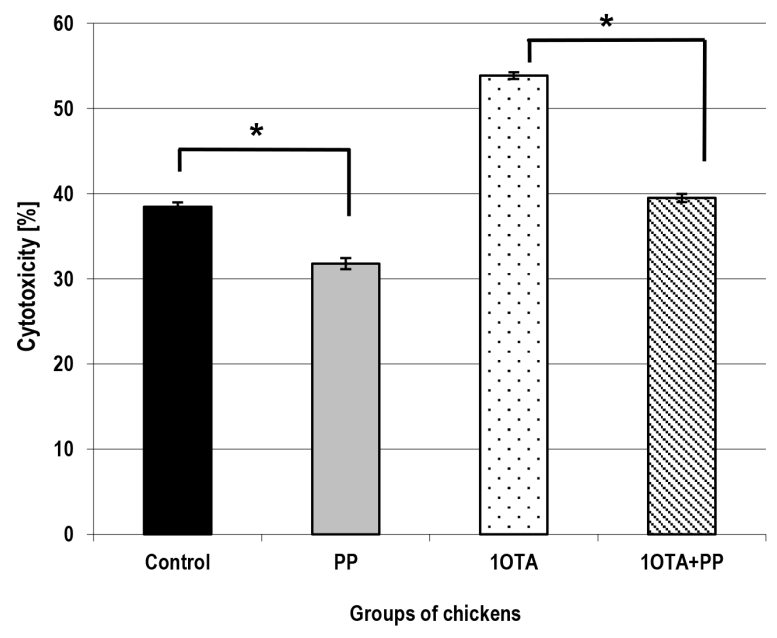

Figure 2. Cytotoxicity of the faecal water of chickens after feeding with probiotic preparation and/or ochratoxin $A$.

Asterisks indicate significant differences $(P<0.05)$. The results displayed are means $( \pm$ S.D.) of three independent experiments.

After supplementation of the feed with the probiotic preparation, a statistically significant decrease in the cytotoxicity of the faecal water was observed, which was $39.5 \pm 0.5$ for chickens fed feed contaminated with $1 \mathrm{mg} /$ $\mathrm{kg}$ of OTA (OTA + PP group).

\section{DISCUSSION}

Biological detoxification of mycotoxins in food, raw products, mixed protein feeds and also in human and animal organisms is a relatively new and promising method. Several microorganisms have been used to eliminate mycotoxins: Acinetobacter calcoaceticus, Aspergillus niger, Bifidobacterium sp., Lactobacillus sp., Enterococcus faecium, Pseudomonas sp. and Saccharomyces sp. strains (Sangare et al., 2014; Styriak et al., 2001; Topcu et al., 2010; Vinderola and Ritieni, 2015). Special attention should be paid to lactic acid bacteria because of their favourable influence on human organisms (probiotic bacteria) and widespread use in the production of fermented foods. These bacteria inhibit the growth of moulds as well as mycotoxins production (Madrigal-Santillán et al., 2006).

The aim of our study was to check if the probiotic preparation (composed of lactic acid bacteria, yeasts and Yucca schidigera extract) influenced the genotoxicity and cytotoxicity of the faecal water of chickens fed OTA contaminated feed. We observed that genotoxicity of the faecal water occurred both in the presence or absence of OTA. However, after supplementation of the feed with the probiotic preparation, genotoxicity decreased in a statistically significant manner. The decrease was more pronounced in the group of chickens fed feed contaminated with OTA (OTA+PP). Therefore, supplementation with the probiotic preparation contributes to the reduction of genotoxicity of the faecal water of chickens fed OTA contaminated feed. The mechanism underlying this effect may be associated with the ability of the probiotic preparation to bind OTA, resulting in its decreased concentration in the chicken colon, although the supplementation of feed with the probiotic preparation only (PP) also decreased DNA damage in the control group. After the supplementation of feed with the probiotic preparation, a statistically significant decrease in the cytotoxicity of faecal water was observed in chickens fed feed contaminated with $1 \mathrm{mg} / \mathrm{kg}$ of OTA (OTA + PP group).
In order to investigate the mechanisms which account for the removal of mycotoxins by LAB, the effects of viable and heat inactivated bacteria were compared in a number of studies (Haskard et al., 2001). Additionally, the bacteria were treated with enzymes (such as pronase $\mathrm{E}$ and lipase) or periodate which cause alterations in the structure of the cell walls (Fuchs et al., 2008). On the basis of the results obtained in those experiments, it was postulated that the removal of aflatoxin $B_{1}$ and zearalenone is due to the non-covalent binding of the toxins to the carbohydrate moieties of the cell walls. The detoxification of heterocyclic aromatic amines was also explained by this mechanism (Knasmüller et al., 2001). However, since a decrease in their toxic effects was also seen with cytosolic preparations of LAB, it was hypothesized that other mechanisms (e.g. interactions with short chain fatty acids) may also play a role (Stidl et al., 2007).

The mechanisms involved in the cellular toxicity of OTA are still unresolved. Distinct mechanisms such as active transport by organic anion transporters and cellular accumulation (Doorten et al., 2006), as well as the chelation of OTA with cellular $\mathrm{Fe}^{2+}$ molecules resulting in an increased production of ROS, have been proposed to mediate OTA toxicity (Schaaf et al., 2002). Cellular DNA damage has been linked in several studies to biotransformation processes, both in vitro and in vivo, as an increased number of DNA adducts were found in human bronchial epithelial cells expressing CYP2C9 (El Adlouni et al., 2000) and kidney microsomes (ObrechtPflumio and Dirheimer, 2000) as well as in mice (Obrecht-Pflumio et al., 1996), rats and pigs (Faucet et al., 2004) treated with OTA. OTA induced mutations on the lacZ' gene in NIH/3T3 cells, transfected with distinct human CYP450 enzymes (de Groene et al., 1996). These cells, transfected with a specific human CYP450 enzyme and at the same time with human oxidoreductase were used in the experiments described here, directed to the analysis of single-stranded DNA breaks (SSBs) following single cell electrophoresis (comet assay) (Doorten et al., 2006).

Several lines of evidence indicate that the carcinogenic action of OTA is correlated with its genotoxicity, as reflected by DNA adduct formation (Castegnaro et al., 1998; Pinelli et al., 1999), leading to mutagenic effects (Malaveille et al., 1991; de Groene et al., 1996). DNAxenobiotic binding is considered to be a critical step in the initiation of mutagenesis and carcinogenesis (Miller \& Miller, 1981). The process of chemical carcinogenesis is initiated by the covalent binding of carcinogens or their reactive metabolites to DNA, thus forming DNA adducts (Pinelli et al., 1999). There is a good correlation between DNA adduct formation and the frequency of mutations (for a review see Lutz \& Gaylor, 1996). To interact with cellular macromolecules and thus initiate cancer, most chemical carcinogens require metabolic activation (Miller \& Miller, 1981), but the metabolic pathways involved in OTA toxicity and genotoxicity remain poorly understood (Pinelli et al., 1999).

There are several mechanisms for OTA toxicity at the cellular level. OTA is a competitor of phenylalaninetRNA ligase, thereby inhibiting protein synthesis. The presence of phenylalanine or aspartame (an analogue of phenylalanine) decreases toxicity by competition with OTA (Creppy et al., 2004; Bayman \& Baber, 2006). Other enzymes are also affected by exposure to OTA. Other mechanisms include formation of DNA adducts, apoptosis, interference with the cytoskeleton, lipid peroxidation and inhibition of mitochondrial respiration (Bayman \& Baker, 2006). 
The cytotoxicity of ochratoxin A has been investigated by several authors and $\mathrm{EC}_{50}$ values were generally observed to lie within the micromolar range. Differences between the specific $\mathrm{EC}_{50} \mathrm{~s}$ reported can probably be attributed to the use of different cell lines, different endpoints (e.g., MT'T reduction, neutral red uptake, cell counting or $\mathrm{LDH}$ release) or indeed to the presence or absence of serum in the culture medium (Dietrich et al., 2001; Heussner, 2006).

\section{CONCLUSION}

In summary, our results show that the probiotic preparation decreases the genotoxicity of the faecal water of chickens fed feed contaminated with $1 \mathrm{mg} / \mathrm{kg}$ ochratoxin $\mathrm{A}$ and can be considered as a preventive agent in poultry breeding.

\section{Acknowledgements}

The study was supported by the Polish State Committee for Research (grant R12 028 01). We would like to thank PhD Malgorzata Piotrowska from Institute of Fermentation Technology and Microbiology for help in preparing ochratoxin A used in the test.

The results were presented at the $6^{\text {th }}$ International Weigl Conference on Microbiology, Gdańsk, 2015.

\section{REFERENCES}

Akande KE, Abubaker MM, Adegbola TA, Bogoro SE (2006) Nutritinal and health implications of mycotoxins in animal feeds: a review. Pakistan J Nutr 5: 398-403.

Allameh A, Safamehr A, Mirhandi S, Shivazad M, Razzaghi-Abyaneh M, Afshar-Naderi A (2005) Evaluation of biochemical and production parameters of broiler chicks fed ammonia treated aflatoxin contaminated maize grains. Anim Feed Sci Tech 122: 289-301. DOI:10.1016/j.anifeedsci.2005.03.005.

Bayman P, Baker JL (2006) Ochratoxins: A global perspective. Mycopathologia 162: 215-223. DOI:10.1007/s11046-006-0055-4.

Blasiak J, Kowalik J (2000) A comparison of the in vitro genotoxicity of tri- and hexavalent chromium. Mutat Res 649: 135-145. DOI:10.1016/S1383-5718(00)00065-6.

Castegnaro M, Mohr U, Pfohl-Leszkowicz A, Estève J, Steinmann J, Tillman T, Michelon J, Bartsch H (1998) Sex- and strain-specific induction of renal tumors by ochratoxin A in rats correlates with DNA adduction. Int J Cancer 77: 70-75. DOI: 10.1002/(SICI)10970215(19980703).

Creppy EE, Chiarappa P, Baudrimont I, Borracci P, Moukha S, Carratù MR (2004) Synergistic effects of fumonisin $B_{1}$ and ochratoxin A: are in vitro cytotoxicity data predictive of in vivo acute toxicity? Toxicology 201: 115-123. DOI: 10.1016/j.tox.2004.04.008.

de Groene EM, Hassing IG, Blom MJ, Seinen W, Fink-Gremmels J, Horbach GJ (1996) Development of human cytochrome P450-expressing cell lines: application in mutagenicity testing of ochratoxin A. Cancer Res 56: 299-305.

Dietrich DR, O'Brien E, Stack ME, Heussner AH (2001) Species- and sex-specific renal cytotoxicity of ochratoxin A and B in vitro. Exp. Toxicol Pathol 53: 215-225.

Doorten YS, Nijmeijer S, de Nijs-Tjon L, Fink-Gremmels J (2006) Metabolism-mediated Ochratoxin A genotoxicity in the single-cell gel electrophoresis (Comet) assay. Food Chem Toxicol 44: 261-270. DOI: 10.1016/j.fct.2005.07.009.

El Adlouni C, Pinelli E, Azémar B, Zaoui D, Beaune P, Pfohl-Leszkowicz A (2000) Phenobarbital increases DNA adduct and metabolites formed by ochratoxin A: role of CYP 2C9 and microsomal glutathione-S-transferase. Environ Mol Mutagen 35: 123-131. DOI: 10.1002/ (SICI)1098-2280(2000).

El-Nezami H, Mykkänen H, Kankaanpää P, Salminen S, Ahokas J (2000) Ability of Lactobacillus and Propionibacterium strains to remove aflatoxin $\mathrm{B}_{1}$ from the chicken duodeum. J Food Prot 63: 549-552.

FAO/WHO (2001) Safety evaluation of certain mycotoxins in food Joint FAO/WHO Expert Committee on Food Additives, 56 th Meeting, Geneva, 6-15 February.

Faucet V, Pfohl-Leszkowicz A, Dai J, Castegnaro M, Manderville RA (2004) Evidence for covalent DNA adduction by ochratoxin A following chronic exposure to rat and subacute exposure to pig. Chem Res Toxicol 17: 1289-1296. DOI: 10.1021/tx049877s.
Fraga M, Curvella F, Gatti M, Cavaglieri L, Dalcero A (2007) Potential aflatoxin and ochratoxin A production by Aspergillus species in poultry feed processing. Vet Res Com 31: 343-353. DOI:10.1007/ s11259-006-3434-x.

Fuchs S, Sontag G, Stidl R, Ehrilich V, Kundi M, Knasmüller S (2008) Detoxification of patulin and ochratoxin A, two abundant mycotoxins, by lactic acid bacteria. Food Chem Toxicol 43: 1398-1407. DOI: 10.1016/j.fct.2007.10.008.

Goldblatt LA (1969) Aflatoxin. Academic Press, New York, USA.

Haskard CA, El-Nezami H, Kankaanpää P, Salminen S, Ahokas J (2001) Surface binding of aflatoxin B1 by lactic acid bacteria. Appl Environ Microbiol 67: 3086-3091. DOI: 10.1128/AEM.67.7.30863091.2001

Heussner AH, Dietrich DR, Brien EO (2006) In vitro investigation of individual and combined cytotoxic effects of ochratoxin A and other selected mycotoxins on renal cells. Toxicol in Vitro 20: 332-341. DOI: $10.1016 /$ j.tiv.2005.08.003.

Höhler D (1998) Ochratoxin A in food and feed: occurrence, legislation and mode of action. Z Ernabrungswiss 37: 2-8.

IARC (1993) Some naturally occurring substances: food items and constituents, heterocyclic aromatic amines and mycotoxins. In IARC Monographs on the Evaluation of Carcinogenic Risk of Chemicals to Humans. vol. 59, Lyon, France.

Knasmüller S, Steinkellner H, Hirschl AM, Rabot S, Nobis EC, Kassie F (2001) Impact of bacteria in dairy products and of the intestinal microflora on the genotoxic and carcinogenic effects of heterocyclic aromatic amines. Mutat Res 480-481: 129-138. DOI: 10.1016/ S0027-5107(01)00176-2.

Lutz W, Gaylor D (1996) Significance of DNA adducts at low dose: shortening the time to spontaneous tumor occurrence. Regul Toxicol Pharmacol 23: 29-34. DOI: 10.1006/rtph.1996.0005.

Madrigal-Santillán E, Madrigal-Bujaider E, Márquez-Márquez R (2006) Antigenotoxic effect of Saccharomyces cerevisiae on the damage produced in mice fed with aflatoxin $\mathrm{B}_{1}$ contaminated corn. Food Chem Toxicol 44: 2058-2063. DOI: 10.1016/j.fct.2006.07.006.

Malaveille C, Brun G, Bartsch H (1991) Genotoxicity of ochratoxin A and structurally related compounds in Escherichia coli strains: studies on their mode of action. In Mycotoxins. Castegnaro M, Plestina R, Dirheimer G, Chernozemsky IN, Bartsch H, eds, pp 261-266. IARC Scientific Publications, Lyon.

Michalowski P, Libudzisz Z, Śliżewska K, Klewicka E, Motyl I, Biernasiak J, Zabierski R (2012) Probiotic growth promoter for poultry. Licence number 212061.

Miller JA, Miller EC (1981) Some current perspectives on chemical carcinogenesis in humans and experimental animals. Cancer Res 38: 1476-1496.

Muscarella M, Palermo C, Rotunno T, Quaranta1 V, D'Antini1 P (2004) Survey of Ochratoxin A in Cereals from Puglia and Basilicata. Vet Res Commun 28: 229-232.

Obrecht-Pflumio S, Dirheimer G (2000) In vitro DNA and dGMP adducts formation caused by ochratoxin A. Chem Biol Interact 127: 29-44. DOI: 10.1016/S0009-2797(00)00169-1.

Obrecht-Pflumio S, Grosse Y, Pfohl-Leszkowicz A, Dirheimer G (1996) Protection by indomethacin and aspirin against genotoxicity of ochratoxin A, particularly in the urinary bladder and kidney. Arch Toxicol 70: 244-248.

Pinelli E, Adlouni C, Pipy B, Quartulli F, Pfohl-Leszkowicz A (1999) Roles of cyclooxygenase and lipoxygenases in ochratoxin A genotoxicity in human epithelial lung cells. Environ Toxicol Pharmacol 7: 95-107. DOI: 10.1016/S1382-6689(99)00008-3.

Puntaric D, Bosnir J, Smit Z, Skes I, Baklaic Z (2001) Ochratoxin A in corn and wheat: geographical association with endemic nephropathy. Croat Med J 42: 175-180.

Rocha MEB, Freire FChO, Maia FEF, Guedes MIF, Rondina D (2014) Mycotoxins and their effects on human and animal health. Food Control 36: 159-165. DOI: 10.1016/j.foodcont.2013.08.021.

Sangare L, Zhao Y, Folly YME, Chang J, Li J, Selvaraj JN, Xing F, Zhou L, Wang Y, Liu Y (2014) Aflatoxin $\mathrm{B}_{1}$ degradation by a Pseudomonas strain. Toxins 6: 3028-3040. DOI: 10.3390/toxins6103028.

Schaaf GI, Nijmeijer SM, Maas RF, Roestenberg P, de Groene EM, Fink-Gremmels J (2002) The role of oxidative stress in the ochratoxin A-mediated toxicity in proximal tubular cells. Biochem Biophys Acta 1588: 149-158. DOI: 10.1016/S0925-4439(02)00159-X.

Shetty P, Jespersen L (2006) Saccharomyces cerevisiae and lactic acid bacteria as potential mycotoxin decontaminating agents. Trends Food Sci Tech 17: 48-55. DOI: $10.1016 / j . t i f s .2005 .10 .004$.

Siegel D, Babuscio T (2011) Mycotoxin management in European cereal trading sector. Food Control 22: 1145-1153. DOI: 10.1016/j.foodcont.2011.02.022.

Singh N, McCoy M, Tice R, Schneide E. (1988) A simple technique for quantitation of low levels of DNA damage in individual cells. Exp Cell Res 175: 184-191. DOI: 10.1016/0014-4827(88)90265-0.

Śliżewska K, Libudzisz Z, Piotrowska M, Smulikowska S, Czerwinski J (2012) The new use of probiotic preparation. Licence Number 210685. 
Slizewska K, Nowak A, Libudzisz Z, Blasiak J (2010) Probiotic preparation reduces the faecal water genotoxicity in chickens fed with aflatoxin $\mathrm{B}_{1}$ contaminated fodder. Res Vet Sci 89: 391-395. DOI: 10.1016/j.rvsc.2010.04.004.

Stidl R, Fuchs S, Koller V, Marian B, Sontag G, Ehrlich V, Knasmüeller S (2007) DNA-protective properties of lactic acid bacteria. In Synthetic and Natural Compounds in Cancer Therapy and Prevention. Durackova Z, Slamenova D, eds. Bratislava, Slovakia.

Styriak I, Conková E, Kmet V, Böhm J, Razzazi E (2001) The use of yeast for microbial degradation of some selected mycotoxin. Mycotoxin Res 174: 24-27.
Topcu A, Bulat T, Wishah R, Boyaci IH (2010) Detoxification of aflatoxin $\mathrm{B}_{1}$ and patulin by Enterococcus faecium strains. Int J Food Microbiol 139: 202-205. DOI: 10.1016/j.ijfoodmicro.2010.03.006.

Van der Merwe KJ, Steyn PS, Fourie L, Scoot DB, Theron JJ (1965)

Ochratoxin A, a Toxic Metabolite produced by Aspergillus ochraceus Wilh. Nature 205: 1112-1113. DOI: 10.1038/2051112a0.

Vinderola G, Ritieni A (2015) Role of probiotics against mycotoxins and their deleterious effects. J Food Res 4: 10-21. DOI: 10.5539/ jfr.v4n1p10. 